Research Note

\title{
A Description of Nail Biting Habit in Elementary School Children
}

\author{
Yetty Herdiyati and Nasya Daniya Marhani \\ Pedodontia Department Faculty of Dentistry, Universitas Padjadjaran/Dental Hospital University of Padjadjaran, \\ Sekeloa Selatan Number 1 Bandung 40132-Indonesia
}

\author{
Article history \\ Received: 30-03-2017 \\ Revised: 28-05-2017 \\ Accepted: 03-06-2017 \\ Corresponding Author: \\ Yetty Herdiyati \\ Pedodontia Department Faculty \\ of Dentistry, Universitas \\ Padjadjaran/Dental Hospital \\ University of Padjadjaran, \\ Sekeloa Selatan Number 1 \\ Bandung 40132- Indonesia \\ Email: yetunpad@gmail.com
}

\begin{abstract}
Nail biting is one of the oral habits that can harm teeth and adjust the structure. The aim of this study is to get the data which help to describe the habit of nail biting in elementary school students in Coblong sub-district in Bandung. This study was conducted using descriptive survey method. The samples were selected using a multi-stage sampling technique. The data of nail biting habit in children was obtained from clinical examination and questionnaires answered by parents as supporting data. The results showed that $25.2 \%$ of elementary school students in Coblong sub-district in Bandung have a common nail biting habit, $29.4 \%$ lying in age bracket of 9 years old, $57.5 \%$ are boys, $41.3 \%$ bite one nail, $24.6 \%$ bite thumbnail and $48.5 \%$ have attrition effect on their teeth. The conclusion of this study is that most nail biters in elementary students are boys who are mostly aged 9 years old. Most nail biters only bite one nail which is the thumb as the most fingernail bitten. The highest nail biting effect towards teeth is attrition.
\end{abstract}

Keywords: Biting, Elementary School, Nail and Students

\section{Introduction}

Oral health and nail biting is an important part of health which has little empirical research focusing specifically on this topic (Claffey et al., 1994). Banks and Yi (2002) discuss (1) why young children bite, (2) how common biting problems are, (3) what interventions might be considered and (4) how teachers or caregivers can interact with and involve parents in dealing with biting behavior.

Biting is one cause of conflicts within children and also a cause of oral health problems. In the past, the level of oral health was measured by the presence or absence of diseases of the mouth, now various aspects such as the psycho-social aspects and impact on quality of life are also considered (Garde et al., 2013). This is true due new research which shows that once a child turns 3 years old but still biting, it then may indicate other behavioural problems, especially if the biting incidents are frequent (Banks and Yi, 2002). Oral habit is a normal part of child development. Because of the developmental nature of most biting, experts stress that biting is not something to blame on the child, parents, or teachers (Greenman and Stonehouse, 1994; Banks and Yi, 2002).

However, if sustained, it can put pressure disproportionate harm to the development of teeth and jaws, such as changes in the position of teeth and occlusion (Finn, 1973; Tandon, 2009). Nail biting is interpreted as an act of biting the cuticle of the nail, soft tissue or the skin around the nail and the nail itself. Nail biting generally appears in children at the time began to feel the rejection or pressure, as do school work or will take the test, or when feeling emotional obtained about (Finn, 1973; Motta et al., 2012).

Nail biting is a habit that normally appears after the sucking age. The incidence of nail biting zero or no before the age of 3 years, rose sharply at the age of 4-6 years, constant at the age of 7-10 years and then increased again until at its peak during puberty (Tandon, 2009). The incidence of nail biting relatively much until the age of 10 years and more in boys than girls ${ }^{5}$.This habit will be increased until puberty and begin to disappear at about the age of 15 years, in which the nail replaced by other objects such as pencils, hair, candy, cigarettes, or switch bite and chew other objects (Finn, 1973; Tandon, 2009).

The pressure resulting from nail biting can cause malocclusion, including crowding, rotation and attrition incisal edge incisors upper and lower jaw, protrusion of the maxillary incisors and maxillary incisor diastema. Non-physiological style derived from nail biting can cause root resorption, alveolar bone destruction and 
craniomandibular dysfunction (Ghanizadeh et al., 2013; Sousa et al., 2010). Other effects that may arise include inflammation in the area around the nail and bacterial infections that cause problems in digestion and surrounding area (Sachan and Chaturvedi, 2012).

\section{Materials and Methods}

This study used survey method. To select the sample, multi-stage sampling technique was used which took five elementary schools in the District of Coblong, Bandung, which is $10 \%$ of the total primary school, then have the class to be studied and obtained a total sample of 671 children.

After informed consent was collected, clinical examination to see signs of nail biting in children's teeth and then the questionnaire given to parents as additional data research. The results were analyzed and presented in table form.

\section{Results}

The results have been briefly presented in table form. Then later a brief discussion and interpretation regarding each table have also been presented as seen below.

\section{Discussion}

Table 1 shows the total number of children who have a habit of biting nails which is 167 out of 671 children. Table 2 shows the number of children who have nail biting habit is most prevalent at the age of 9 years. According to Tanaka et al. (2008) nail biting will be stable at the age of 7-10 years and continues to increase until the age of puberty. These results are also consistent with research of Malone and Massler in 1952 established (as cited by Shamsudin, 2013) that nail biting observed at ages 8, 9 and 10 years (Sachan and Chaturvedi, 2012).

Table 3 shows the nail biting is more common in boys than girls. This is consistent with the theory that nail biting is not always associated with the sexes, but is more common in men than women (Ghanizadeh et al., 2013; Aboujaoude and Korran, 2010). The result of this research study is slightly different from Motta et al. (2012) in which more girls were found to have nail biting than men.

Table 4 shows the majority of children just bite one finger, followed by two fingers and ten or the entire finger. This result is slightly different from Malone and Massler study in which $70 \%$ of all samples bite the whole fingers.

Type of finger often bitten by the children is shown in Table 5, which found the majority of children bite the thumb and index finger. These results are consistent with research Shamsudin (2013), which showed $35.6 \%$ of children biting index finger.

Table 6 shows the most nail-biting effect is attrition. Attrition, protrusion and diastema an effect that often arises from nail biting habit, which was the effect of continuous pressure obtained at the time of the child nail biting. Keep in mind that the duration, intensity and frequency of nail biting children have an important role in the effect of this practice on the condition of the teeth (Finn, 1973).

Table 1. Total of children who bite and don't bite nails

\begin{tabular}{|c|c|c|c|c|c|c|}
\hline \multirow[b]{2}{*}{ School name } & \multicolumn{2}{|c|}{ Bite nails } & \multicolumn{2}{|c|}{ Don't bite nails } & \multicolumn{2}{|c|}{ Total } \\
\hline & $\mathrm{n}$ & $\%$ & $\mathrm{n}$ & $\%$ & $\mathrm{n}$ & $\%$ \\
\hline Darul hikam elementary school & 20 & 2.9 & 47 & 7.0 & 67 & 9.9 \\
\hline Tilil elementary school & 59 & 8.8 & 90 & 13.4 & 149 & 22.2 \\
\hline Cisitu elementary school & 34 & 5.1 & 138 & 20.5 & 172 & 25.6 \\
\hline Tikukur elementary school & 22 & 3.3 & 149 & 22.2 & 171 & 25.5 \\
\hline Cihampelas elementary school & 32 & 4.8 & 80 & 12.0 & 112 & 16.8 \\
\hline Total & 167 & 24.9 & 504 & 75.1 & 671 & 100.0 \\
\hline
\end{tabular}

Table 2. Total of children who bite and don't bite nails based on age

\begin{tabular}{|c|c|c|c|c|c|c|c|c|c|c|c|c|}
\hline \multirow[b]{2}{*}{ Age } & \multicolumn{2}{|c|}{ ES 1} & \multicolumn{2}{|c|}{ ES 2} & \multicolumn{2}{|c|}{ ES 3} & \multicolumn{2}{|c|}{ ES 4} & \multicolumn{2}{|c|}{ ES 5} & \multicolumn{2}{|c|}{ Total } \\
\hline & $\mathrm{n}$ & $\%$ & $\mathrm{n}$ & $\%$ & $\mathrm{n}$ & $\%$ & $\mathrm{n}$ & $\%$ & $\mathrm{n}$ & $\%$ & $\mathrm{n}$ & $\%$ \\
\hline 6 & 0 & 0.0 & 0 & 0.0 & 0 & 0.00 & 0 & 0.00 & 0 & 0.0 & 0 & 0.0 \\
\hline 7 & 6 & 3.6 & 5 & 2.9 & 4 & 2.45 & 4 & 2.45 & 3 & 1.8 & 22 & 13.2 \\
\hline 8 & 9 & 5.3 & 6 & 3.6 & 4 & 2.4 & 3 & 1.8 & 3 & 1.8 & 25 & 14.9 \\
\hline 9 & 3 & 1.8 & 19 & 11,4 & 11 & 6.6 & 3 & 1.8 & 13 & 7.8 & 49 & 29.4 \\
\hline 10 & 2 & 1.2 & 17 & 10.2 & 6 & 3.6 & 3 & 1.8 & 7 & 4.1 & 35 & 20.9 \\
\hline 11 & 1 & 0.6 & 10 & 5.9 & 9 & 5.3 & 8 & 5.1 & 5 & 2.9 & 33 & 19.8 \\
\hline 12 & 0 & 0 & 1 & 0.6 & 0 & 0 & 1 & 0.6 & 1 & 0.6 & 3 & 1.8 \\
\hline
\end{tabular}

Notes: ES 1 = Darul hikam elementary school; ES 2 = Tilil elementary school; ES 3 = Cisitu elementary school; ES $4=$ Tikukur elementary school; ES 5 = Cihampelas elementary school 
Yetty Herdiyati and Nasya Daniya Marhani / OnLine Journal of Biological Sciences 2017, 17 (2): 66.69 DOI: 10.3844/ojbsci.2017.66.69

Table 3. Total of children who bite and don't bite nails based on sex

\begin{tabular}{|c|c|c|c|c|c|c|}
\hline \multirow[b]{2}{*}{ School name } & \multicolumn{2}{|c|}{ Boys } & \multicolumn{2}{|c|}{ Girls } & \multicolumn{2}{|c|}{ Total } \\
\hline & $\mathrm{n}$ & $\%$ & $\mathrm{n}$ & $\%$ & $\mathrm{n}$ & $\%$ \\
\hline Darul hikam elementary school & 10 & $5,9.0$ & 10 & $6,0.0$ & 20 & 11.9 \\
\hline Tilil elementary school & 40 & 23.9 & 19 & 11.4 & 59 & 35.3 \\
\hline Cisitu elementary school & 16 & 9.6 & 18 & 10.8 & 34 & 20.4 \\
\hline Tikukur elementary school & 17 & 1.0 & 5 & 12.2 & 22 & 13.2 \\
\hline Cihampelas elementary school & 13 & 7.8 & 19 & 11.4 & 32 & 19.2 \\
\hline Total & 96 & $57,5.0$ & 71 & $42,5.0$ & 167 & 100 \\
\hline
\end{tabular}

Table 4. Total finger bitten by children

\begin{tabular}{|c|c|c|c|c|c|c|c|c|c|c|c|c|}
\hline \multirow[b]{2}{*}{ Total finger } & \multicolumn{2}{|c|}{ ES 1} & \multicolumn{2}{|c|}{ ES 2} & \multicolumn{2}{|c|}{ ES 3} & \multicolumn{2}{|c|}{ ES 4} & \multicolumn{2}{|c|}{ ES 5} & \multicolumn{2}{|c|}{ Total } \\
\hline & $\mathrm{n}$ & $\%$ & $\mathrm{n}$ & $\%$ & $\mathrm{n}$ & $\%$ & $\mathrm{n}$ & $\%$ & $\mathrm{n}$ & $\%$ & $\mathrm{n}$ & $\%$ \\
\hline 1 & 8 & 4.8 & 21 & 12.6 & 14 & 8.4 & 7 & 4.2 & 19 & 11.3 & 69 & 41.3 \\
\hline 2 & 4 & 2.4 & 18 & 10.5 & 6 & 3.8 & 3 & 1.9 & 1 & $0,6.0$ & 32 & 19.2 \\
\hline 3 & 1 & 0.6 & 6 & 3.8 & 1 & 0.6 & 1 & 0.6 & 2 & 1.2 & 11 & 6.6 \\
\hline 4 & 0 & 0.0 & 4 & 2.4 & 0 & 0.0 & 2 & 1.2 & 0 & 0.0 & 6 & 3.6 \\
\hline 5 & 5 & 2.9 & 3 & 1.9 & 5 & 2.9 & 3 & 1.9 & 5 & 2.9 & 21 & 12.5 \\
\hline 6 & 0 & 0.0 & 1 & 0.6 & 0 & 0.0 & 0 & 0.0 & 0 & 0.0 & 1 & 0.6 \\
\hline 7 & 0 & 0.0 & 1 & 0.6 & 0 & 0.0 & 0 & 0.0 & 0 & 0.0 & 1 & 0.6 \\
\hline 8 & 0 & 0.0 & 0 & 0.0 & 0 & 0.0 & 0 & 0.0 & 0 & 0.0 & 0 & 0.0 \\
\hline 9 & 0 & 0.0 & 0 & 0.0 & 0 & 0.0 & 0 & 0.0 & 0 & 0.0 & 0 & 0.0 \\
\hline 10 & 2 & 1.2 & 5 & 2.9 & 8 & 4.8 & 6 & 3.8 & 5 & 2.9 & 26 & 15.6 \\
\hline
\end{tabular}

Table 5. Type of finger bitten by the children

\begin{tabular}{|c|c|c|c|c|c|c|c|c|c|c|}
\hline \multirow[b]{3}{*}{ School name } & \multicolumn{10}{|c|}{ Type of finger } \\
\hline & \multicolumn{2}{|c|}{ Thumb } & \multicolumn{2}{|c|}{ Index finger } & \multicolumn{2}{|c|}{ Middle finger } & \multicolumn{2}{|c|}{ Ring finger } & \multicolumn{2}{|c|}{ Little finger } \\
\hline & $\mathrm{n}$ & $\%$ & $\mathrm{n}$ & $\%$ & $\mathrm{n}$ & $\%$ & $\mathrm{n}$ & $\%$ & $\mathrm{n}$ & $\%$ \\
\hline$\overline{\text { ES } 1}$ & 10 & 2.1 & 18 & 3.8 & 12 & 2.6 & 7 & 1.5 & 7 & 1.5 \\
\hline ES 1 & 59 & 12.5 & 29 & 6.2 & 40 & 8.5 & 27 & 5.7 & 16 & 3.4 \\
\hline ES 1 & 17 & 3.6 & 26 & 5.5 & 18 & 3.8 & 12 & 2.6 & 17 & 3.6 \\
\hline ES 1 & 13 & 2.8 & 18 & 3.8 & 12 & 2.6 & 12 & 2.6 & 14 & 2.9 \\
\hline ES 1 & 17 & 3.6 & 13 & 2.8 & 17 & 3.5 & 20 & 4.2 & 20 & 4.3 \\
\hline Total & 116 & 24.6 & 104 & 22.1 & 99 & 21.0 & 78 & $16,6.0$ & 74 & 15.7 \\
\hline
\end{tabular}

Table 6. Description of nail biting on children's teeth

\begin{tabular}{|c|c|c|c|c|c|c|c|c|c|c|c|c|c|c|}
\hline \multirow[b]{2}{*}{ Name } & \multicolumn{2}{|c|}{ A } & \multicolumn{2}{|l|}{$\mathrm{D}$} & \multicolumn{2}{|l|}{$\mathrm{P}$} & \multicolumn{2}{|c|}{$A+D$} & \multicolumn{2}{|c|}{$\mathrm{A}+\mathrm{P}$} & \multicolumn{2}{|c|}{$\mathrm{A}+\mathrm{D}+\mathrm{P}$} & \multicolumn{2}{|l|}{$\mathrm{X}$} \\
\hline & $\mathrm{n}$ & $\%$ & $\mathrm{n}$ & $\%$ & $\mathrm{n}$ & $\%$ & $\mathrm{n}$ & $\%$ & $\mathrm{n}$ & $\%$ & $\mathrm{n}$ & $\%$ & $\mathrm{n}$ & $\%$ \\
\hline$\overline{\text { ES } 1}$ & 5 & 2.9 & 2 & 1.2 & 0 & 0.0 & 2 & 1.2 & 0 & 0.0 & 0 & 0.0 & 11 & 6.6 \\
\hline ES 1 & 21 & 12.6 & 1 & 0.6 & 0 & 0.0 & 10 & 5.9 & 1 & 0.6 & 3 & 1.8 & 23 & 13.8 \\
\hline ES 1 & 11 & 6.6 & 2 & 1.2 & 0 & 0.0 & 1 & 0.6 & 1 & 0.6 & 0 & 0.0 & 19 & 11.3 \\
\hline ES 1 & 9 & 5.4 & 1 & 0.6 & 3 & 1.8 & 6 & 3.6 & 2 & 1.2 & 0 & 0.0 & 1 & 0.6 \\
\hline ES 1 & 6 & 3.6 & 1 & 0.6 & 0 & 0.0 & 4 & $1,9.0$ & 0 & 0.0 & 0 & 0.0 & 21 & $12,6.0$ \\
\hline Total & 52 & 31.1 & 7 & 4.2 & 3 & 1.8 & 23 & 13.2 & 4 & 2.4 & 3 & 1.8 & 75 & 44.9 \\
\hline
\end{tabular}

Notes: A: Atrition; D: Diastem; P: Protrution; X: No visible abnormalities

Table 7. Dominant percentage at each question on overview of nail biting habits in children questionnaire

\begin{tabular}{lllll}
\hline No. & Questions & Answers & Total & $\%$ \\
\hline 1. & Knowing the nail biting habit in children & Yes & 121 & 75.2 \\
2. & The age when children start biting nails & 9 years old & 24 & 12.4 \\
3. & Stopping or not if the child biting nails & Yes & 117 & 70.1 \\
4. & Frequent nile biting in child & Less or equal to 3 times a day & 92 & 55.1 \\
5. & Condition when child bites nails & While watching tv & 86 & 73.5 \\
6. & The reason of nail biting & Don't know & 78 & 46.7 \\
7. & Finger nails that often bitten & Index Finger & 42 & 25.2 \\
8. & Other family members who bite nails & No & 139 & 83.2 \\
9. & Have visited the dentist or not & Yes & 79 & 68.9 \\
10. & The reason of child's first dental visit & Toothache & & 47.3 \\
\hline
\end{tabular}


The results of the questionnaire as supporting data completed by parents can be seen in Table 7 . A total of 121 parents find that their children have a habit of biting her nails, while the rest did not know or did not recognize the child has a habit of biting nails. This can happen because the children just bite nails at school or at home when parents do not see or pay less attention.

The majority of parents tried to stop her if seen biting nails, as many as 117 parents. The intervention is important in the effort to stop the habit in order to prevent further tooth abnormalities (Garde et al., 2013).

Often children nail biting majority of less than or equal to 3 times a day. Frequency is the number of children biting nails in a day, is one of the important roles that affect whether or not changes in the teeth. Generally, the effect will be seen more in children who bite nails excessively with a frequency which is quite often. Many conditions that can stimulate children nail biting, including stress, hunger, fear, emotional conditions that are less stable, or perhaps unconsciously (Tandon).

A total of 86 parents say children nail biting on while watching television. At this time children are likely not aware of that because being focused on television, the television program involving emotional can also make them vent it with a nail-biting.

\section{Conclusion}

This paper basically present results on nail biting among children. The results of this study indicate that the description of the most nail is mostly within the age of 9 years and the male gender. The finger which and at times frequently bitten is the thumb nail. Most of the nail-biting effect is attrition.

\section{Acknowledgment}

We thank all parents and clinical officers who got involved in this study. Indeed without your support, we would not have come up with this paper. We also thank OnLine Journal of Biological Sciences for the motivation and guidelines offered through the review comments.

\section{Author's Contributions}

Yetty Herdiyati: She is the main author, she contributed both in material and finance towards this manuscript.

Nasya Daniya Marhani: She is a research assistant who also contributed greatly to the writing of this manuscript. Her contribution helped the main author get focused on writing the final manuscript.

\section{Ethics}

Required academic procedures have been followed during the writing of this manuscript and there is no plagiarism of any kind. All literature used has been referenced as seen in the paper and the reference part.

\section{References}

Aboujaoude, E. and L.M. Korran, 2010. Impulse Control Disorders. 1st Edn., Cambridge University Press, New York, pp: 144-156.

Banks, R. and S. Yi, 2002. Dealing with biting behaviors in young children.

Claffey, A.E., L.J. Kucharski and R.R. Gratz, 1994. Managing the biting child. Early Child Dev. Care, 99: 93-101.

Garde, J.N., R.K. Suryavanshi, B.A. Jawale, V. Deshmukh and D.P. Dadhe et al., 2013. An epidemiological study to know the prevalence of deleterious oral habits among 6 to 12 year old children. J. Int. Oral Health, 6: 39-43.

Ghanizadeh, A., A. Bathafshan and A. Firoozabadi, 2013. Habit reversal versus object manipulation training for treating nail biting: A randomized controlled clinical trial. Iran. J. Psychiat., 8: 61-67.

Greenman, J. and A.W. Stonehouse, 1994. Reality bites: Biting at the center--part 1. Child Care Inform. Exchange, 99: 85-88.

Finn, S.B., 1973. Clinical Pedodontics. 4th Edn., Saunders, Philadelphia, ISBN-10: 0721636373, pp: 704.

Motta, L.J., T.A. Alfaya and A.F. Marangoni, 2012. Gender as risk factor for mouth breathing and other harmful oral habits in preschoolers. Braz J. Oral Sci., 11: 377-380.

Sachan, A. and T.P. Chaturvedi, 2012. Onychophagia (nail biting), anxiety and malocclusion. Indian J. Dent. Res., 23: 680-682. DOI: 10.4103/0970-9290.107399

Shamsudin, M.F.B., 2013. The Prevalence of Nail Biting Effect towards Children Teeth. Fakultas Kedokteran Gigi. Universitas Padjadjaran. Bandung.

Sousa, D., D. Pinto, R. Araujo, R.O. Rego and J. Moreira-Neto, 2010. Gingival abscess due to an unusual nail-biting habit: A case report. J. Contemp. Dent. Pract., 11: 1-5.

Tanaka, O.M., R.W.F. Vitral, G.Y. Tanaka, A.P. Guerrero and E.S. Camargo, 2008. Nailbiting, or onychophagia: A special habit. Am. J. Orthod. Dentofacial Orthop., 143: 305-308. DOI: 10.1016/j.ajodo.2006.06.023

Tandon, S., 2009. Textbook of Pedodontics. 1st Edn., Paras Medical Publisher, India. 